\title{
THE
}

\section{Class Debates in Intermediate Microeconomics: Social Economics and Pluralist Perspectives}

Ashley J. Provencher

Smita Ramnarain

University of Rhode Island, sramnarain@uri.edu

Follow this and additional works at: https://digitalcommons.uri.edu/ecn_facpubs

The University of Rhode Island Faculty have made this article openly available.

Please let us know how Open Access to this research benefits you.

This is a pre-publication author manuscript of the final, published article.

Terms of Use

This article is made available under the terms and conditions applicable towards Open Access

Policy Articles, as set forth in our Terms of Use.

\section{Citation/Publisher Attribution}

Provencher, A. and S. Ramnarain (2018). Class Debates in Intermediate Microeconomics: Social Economics and Pluralist Perspectives. Forum for Social Economics, 1-19, https://doi.org/10.1080/ 07360932.2018.1447494.

Available at: https://doi.org/10.1080/07360932.2018.1447494

This Article is brought to you for free and open access by the Economics at DigitalCommons@URI. It has been accepted for inclusion in Economics Faculty Publications by an authorized administrator of DigitalCommons@URI. For more information, please contact digitalcommons-group@uri.edu. 
- Provencher, A. and S. Ramnarain (2018), Class Debates in Intermediate Microeconomics: Social Economics and Pluralist Perspectives, Forum for Social Economics, 1-19, https://doi.org/10.1080/07360932.2018.1447494

\title{
Class Debates in Intermediate Microeconomics: Social Economics and Pluralist Perspectives Ashley J. Provencher and Smita Ramnarain ${ }^{\dagger}$
}

\begin{abstract}
This paper proposes the use of class debates in an intermediate level microeconomics course to introduce early- to mid-career undergraduate students to socially embedded and pluralist perspectives, political economic processes, and policy analyses. Using data from three semesters of class debates in an intermediate microeconomics course, we argue that this activity is a beneficial way to stimulate student interest in social economics, especially in the ethical, political economy, and economic justice aspects of economics and policy. We carried out three allied activities: participation in the debate, a learning self-assessment survey, and a five-page memo providing a balanced analysis of the policy conundrums surrounding the issue under discussion. We discuss three aspects of these class debates relevant to social economists: student attention to processes of knowledge construction, cognizance of power in socio-economic life, and engagement with economic justice and ethics.
\end{abstract}

Keywords: pedagogy, pluralism, undergraduate microeconomics, class activity

JEL codes: A22, B5

\section{Introduction}

Notwithstanding David Colander's call for the death of (the term) 'neo-classical economics' (Colander 2000) and recent interventions overhauling the teaching of introductory microeconomics ${ }^{1}$, many argue that economics teaching does not adequately reflect the strides the discipline has taken in displacing the centrality of neoclassical theory (Colander, Holt and Rosser 2004; Becker 2004). As Denis (2009: 7) points out, despite the 'many sciences, many practices, many visions and paradigms' that constitute economics today, the teaching of economics remains largely homogenous. The teaching of intermediate-level microeconomics (henceforth, IME), in particular, remains largely impervious to the critiques and challenges that both mainstream non-neoclassical frameworks (such as behavioral and experimental economics, weak uncertainty and bounded rationality frameworks, or evolutionary game theory) as well as heterodox economics (including, but not limited to feminist, institutionalist, or radical approaches), have mounted against this framework (Mearman 2007; Colander 2000).

The typical intermediate-level course in microeconomics focuses on neoclassical models premised on rationality, the use of utility maximization or profit maximization as criteria of rationality, an emphasis on equilibrium, and a rejection of uncertainty (Dequech 2007; Weintraub 2007; see also Colander, Holt and Rosser 2004). Neoclassical economics (NCE) finds its philosophical roots in utilitarianism

Economics Department, Siena College, Loudonville NY.

† Department of Economics, University of Rhode Island, Kingston RI. sramnarain@uri.edu 
and methodological individualism: it is the optimizing decisions of the individual economic agent choices made at the margin - that explain economic outcomes (Weintraub 2007; Colander 2000). Markets constitute the site where consumers and firms work out their decision problems (Weintraub 2007), and perfect markets are the ideal. The curriculum may include a discussion of factor markets the labor market in particular - and an introduction to the basic tenets of welfare economics. Insofar as factor markets are discussed, the neoclassical framework crystallizes what Polanyi (1944) calls the 'commodity fiction' in liberal economics, by which labor (also land and capital) is organized into a market akin to commodities. This framework thus precludes any discussion of arrangements or behaviors that exist outside of this market mechanism (Polanyi 1944). The toolkit that such a course imparts is centered around solving optimization problems using calculus and 'mathematical formalism as the exclusive method of choice' (Mearman 2008: 7), rather than interrogating what such models leave out, or alternative approaches.

For social economists who desire a more holistic approach to teaching IME - one which integrates the pluralistic, historical, socially-oriented, and normative aspects of economics - the challenge consists of drawing a balance between three pressures in the classroom. First, given the status quo of the discipline, it is important to imbue students with some grasp of the essentials of NCE since it can inform parts of applied elective courses such as labor, health, and public economics, inform policy, and is valuable for subsequent graduate studies in mainstream or heterodox traditions. Second, however, critical reflection on the assumptions, omissions, and commissions of the NCE framework is key to developing student interest in an inquiry into economics, and into what a socially-oriented economics might look like. Examining the political economic, ethical, social justice, and normative aspects of a real-world economic problem can be stepping stone for students who might then be more cognizant of pluralist perspectives and alternative possibilities in economics. Such critical reflection is crucial for students who do not continue with economics and whose only exposure to economics is then the dominant neoclassical model. Defining pluralism ${ }^{2}$ as multiple perspectives and methodologies in economic inquiry, a 'broad range of viewpoints' (Stilwell 2016: 3), these perspectives and methodologies emerge not only from the different branches of heterodox economics but also from non-neoclassical mainstream approaches. Third, students frequently accuse IME of being too theory-centric, 'dry', or 'boring', with few opportunities for hands-on engagement, studentdriven inquiry, or application to ongoing real-world issues. The work is cut out for instructors, then, of making IME resonate with student interest in economic issues and of promoting students' active engagement in learning. 
We propose class debates as an activity for teaching social economics in an IME course. We base our discussion on three semesters of carrying out this exercise in an IME course taught separately by two instructors. Three allied activities - debate participation, a learning self-assessment survey, and a fivepage memo - were assigned to students. Using both qualitative and quantitative data from these activities, we suggest that the class debates were an effective tool to stimulate students' critical thinking on assumptions and outcomes of the textbook neoclassical model to the analysis of a real-world problem. The debates provoked discussions on human values, the role of social norms and institutions, the distribution of wealth and power, and the normative aspects of societal well-being. This critical perspective then provides openings for instructors to introduce students to alternative perspectives in economics. We discuss three aspects of student learning from debates in IME which are relevant to social economists: attention to processes of knowledge construction, cognizance of power in socio-economic life, and engagement with the normative (economic justice and ethics) and historical.

Emami (2015: 82) further notes that the conventional approach to teaching economics - 'with its focus on the teacher as the source of knowledge' and 'the learner as a passive recipient of received knowledge' - is intimately connected to the teaching of economics as a 'monist (versus pluralist), value free and universally applicable way of thinking.' The focus on abstract theory and mathematical formalism in much IME teaching, too, underpins this conventional pedagogical approach. By encouraging students to bring in additional resources to support their arguments, however, the debates create opportunities to upend the top-down pedagogical model by which students are unquestioning recipients of knowledge and enhance student capacity for self-directed learning. As we discuss in the next sections, debate preparation put the onus of research and discovery on students, resulting in greater motivation among them for learning, in taking a critical stance towards the neoclassical model's conclusions, and in openness towards other approaches.

\section{Social economics and pluralist perspectives through class debates in IME: pedagogical approach}

Recent developments in economics, such as game theory, prospect theory, behavioral and experimental economics, ecological economics, and New Institutionalism among others, alongside existing critiques from Marxian, social, feminist, institutionalist, and post-colonial perspectives, have disputed and disproved foundational neoclassical assumptions of far-sighted and consistent rationality, optimization in resource allocation, and methodological individualism. Yet, few of these discussions have found their way into the typical IME curriculum (Colander, Holt and Rosser 2004; Becker 2004; Denis 2009). Mearman (2007: 2) attributes part of this stickiness of curriculum to instructors' 
'sunk capital in teaching materials' as well as the demands such an overhaul would place on (already hard-pressed) instructors.

There are, however, at least two reasons why IME teaching should be overhauled despite this stickiness. First, an IME course focusing solely on neoclassical theory does a disservice to students of economics - especially those who will not pursue advanced economic study - who walk away from an undergraduate microeconomics course with a monist understanding of economics, and with no inkling of its pluralist character. As future policy makers and thought leaders, equating economics with NCE reinforces the exclusion of social, historical, institutional, and political-economic perspectives. Second, centering the neoclassical model in IME teaching contributes to its perceived hegemony, even when such hegemony may no longer exist in reality. As such, students continue to think of the neoclassical model as the norm in economics, and by extension, all other perspectives as aberrant. Indeed, the mass walkouts of students in France that led to the establishment of the postautistic movement in economics, as well as the general discontent of students in undergraduate economics classes who find the content abstract and unconnected to social reality, underscore the importance of revitalizing IME teaching.

Mearman (2007) presents a typology of approaches to pluralizing economics: enriching an orthodox program ('orthodox-plus'), teaching a 'heterodox module', and a 'parallel perspectives' approach. The 'orthodox-plus' approach emerges in response to the practical consideration that opportunities to teach exclusively heterodox material in undergraduate classes may be limited. The heterodox module approach consists of developing a cohesive course that consists on a specific alternative school of thought. The parallel perspectives approach consists of teaching topics of interest first from one perspective, then from the other, to facilitate contrast and comparison.

Extending this typology to teaching IME, we find that an orthodox-plus approach is suitable for instructors of this type of course. With such an approach instructors can provide students with an understanding of the basics of NCE while at the same time laying the foundation for its critical assessment using a social economics lens in terms of tackling real world issues. Mearman notes (2007: 12-3) that this approach allows students to deconstruct the assumptions used in neoclassical theory and examine these for their realism and representativeness of human behavior, thus 'offsetting the apathy many students feel when studying economics' (13). Students are forced to confront the ahistoricity of NCE, its claims of value-neutrality, and its distributional or political-economic implications. The orthodox-plus approach offers alternatives for students to consider, both from mainstream non-neoclassical as well as heterodox approaches. 
We argue that the 'heterodox module' approach or the 'parallel perspectives' approach are less amenable for an IME course. The heterodox module, which may either be a course focusing on a single heterodox perspective, or an amalgam of several heterodox perspectives, is more suitable for upper-level specialized courses where students have had some exposure to economics. Further, in programs which consist of a defined core curriculum (pre-requisites), consisting of introductory and intermediate micro- and macroeconomics followed by student-chosen electives, there is no guarantee that students will be exposed to alternative perspectives unless they self-select into an elective that explicitly offers a heterodox framework. By integrating social economics and pluralist perspectives into a core intermediate theory course, therefore, we are able to guarantee that all economics students have this exposure. The 'parallel perspectives' approach, while allowing for detailed comparative and critical treatment of both orthodox and heterodox economics (Mearman 2007), may prove overwhelming for students in an IME course where the learning curve for policy analysis, problem solving, and critical thinking is already steep. Finally, the orthodox-plus approach allows for the introduction of plural perspectives - which may be based in different economic traditions throughout the semester, as opposed to a single alternative perspective. Since our objective was to expose students to a variety of perspectives, we found the orthodox-plus approach in devising and using the class debates activity to serve our needs best.

The design of the debate - which emphasizes student initiative in learning and a discussion-based approach - provides a starting point for students to think through and articulate weaknesses of the neoclassical framework. Instructors can capitalize on the discomfort the debates produce to introduce social economics, alternative theoretical frameworks, and political economy approaches through assigning additional reading and developing new course materials. Such a strategy also allows for greater flexibility in course design. Finally, this approach allows instructors to build a level of comfort with the foundations of NCE in students, while at the same time not reinforce its dominance in the theoretical space of economics.

We now turn to the mechanics of implementing the debates and to the engagement with social economics that this activity promotes for students.

\section{Class debates: organization and mechanics}

The debate topics and structure compelled teams to identify neoclassical policy predictions, 
critique assumptions and the conclusions that follow, and offer counterarguments or an alternative conceptualization which may be based on pluralist perspectives. A minimum of four debates was held each semester (a maximum of six), with all topics announced at the start of the semester. While the instructor chose debate topics, such that they corresponded with specific microeconomic concepts (see Table 1), students choose which debate to participate in. This choice provides students with an opportunity to take initiative in directing their own learning.

\section{INSERT TABLE 1 HERE}

The debate questions were worded as they appear in Table l: we expected that the provocative wording would foster engagement as students attempted to articulate critiques against how the questions themselves were framed. Hess (2004: 257) remarks that a 'general aversion to controversy ... make(s) the terrain of controversial issues teaching especially treacherous now' even as significant evidence exists that discussions of controversial issues in an open classroom climate can enhance critical thinking, promote non-simplistic engagement with political and economic issues of the time, and ultimately influence future civic behavior (ibid.).

Setting debate questions in this manner has several advantages: first, students had to confront and reason through their own pre-conceived notions on the given economic issue through participation. Second, rather than receive perspectives from the instructor - which may be viewed as indoctrinating - students were forced to consider other points of view and counter them based on evidence or through reason-based arguments. As a result, any critique of the neoclassical model that students arrived at - was a product of a bottom-up peer learning process, as opposed to instructor instruction. Third, such an exercise urged students to consider the personal experience of peers (say, with charter schools or with college education) but to also go beyond these, especially when data or evidence ran counter to such experiences.

Each team then separated into Pro and Con sides consisting of two to four students per side. While the typical class size ranged from 12 to 27 students in this context, its scale may be adjusted for larger class sizes of up to 50 students (six debates, with eight students per debate). Three allied activities were carried out: participation in the debate, a learning self-assessment survey, and a five-page memo providing a balanced analysis of ethical, distributional, and policy conundrums surrounding the issue under discussion. Each activity is described below.

\subsection{Debate and debriefing}


Each debate consisted of five rounds, lasting a total of 40 minutes. The remaining class time was used to debrief and fill out learning assessment surveys. Debriefing included the next class period as well. The debate structure is presented in Table $2 .{ }^{3}$ Each team started with a position presentation: a general summary of the issues under consideration, and a rationale for the position they were taking. One rule was that sources of data and specific arguments be cited clearly.

Work periods were built in to the debate structure. Students in the audience (that is, those who were not on the debating teams) were encouraged at this point to provide the team of their choice with assistance in the form of additional arguments or data. Teams presented their rebuttal in round two and responses in round three. Round four consisted of audience questions. Participation points for questions or assistance to debate teams during work periods stimulated audience engagement. Teams summarized their arguments in the final round. The assessment rubric for the debate consisted of five aspects: ability to explain or contest the issue using economic theory and data, confidence in presenting their position as well as in responding to counterarguments, knowledge of economic methods to analyze the topic, clarity of arguments, and coordination with team members.

\section{INSERT TABLE 2 HERE}

When students arrived at a critique of the neoclassical model through the debate, there was greater ownership of the learning process. For instance, in the debate Is discrimination on the basis of gender a major factor in US labor markets today. ${ }^{2}$ students tentatively arrived at the link between the household and the labor market for female labor force participation and achievement. When informed of the existence of such critiques in feminist economics, students became more interested in learning about feminist economics more formally. At this point the instructor assigned a reading related to this issue for the next class when the debate was debriefed. In this particular example, follow-up readings for debriefing included Shulman (1996) and in another semester, excerpts from Woolley (1993), and the entry 'Discrimination, Theories of' from Peterson and Lewis' (1999). Instructors may choose readings based on their discretion, which validate critiques of the neoclassical model or provide alternative formulations and explanations for the issue under examination. With the junk food debate, when food deserts arise in a discussion of structural factors impacting distribution, follow-up readings could be assigned from Sen (1999) and Guthman (2011). On one occasion, the debriefing consisted of field trip to a local organization working in inner-city neighborhoods to provide fresh food (discussed further in Section 4.3). 


\subsection{Learning self-assessment survey}

A learning self-assessment survey was administered to all students following the debate and sought to capture a student's self-assessment with respect to four learning objectives. Students were asked if they felt that the debate had allowed them to critically analyze and interpret economic data, apply economic reasoning, appreciate the limitations of neoclassical microeconomics in real world situations, and understand the ethical and historical dimensions of economic dilemmas. The survey included both multiple-choice and open-ended questions, and the findings from the self-assessment are reported in Table 3.

Since students may arguably over- or under-estimate their learning in self-assessments, we also rely on arguments made during the debates and those found in student memos for specific examples. For almost all of the debates, two separate sets of notes were maintained by each of the co-authors of this paper. This allowed us to crosscheck student arguments for each debate.

\section{INSERT TABLE 3 HERE}

\subsection{Memo}

One week after the debate, the speakers handed in a five-page memo providing a complete analysis of the policy conundrums surrounding the issue under discussion, regardless of their position during the debate. When writing their memo, students could only use peer-reviewed academic sources. These included sources used by either team as well as assigned debriefing articles. The memo empowered students to reflect upon competing perspectives on a given issue and critically synthesize arguments they had heard or made during the debate.

\subsection{Class participation}

All students in the class were required to read one or two assigned articles for each debate, each addressing the debate topic. ${ }^{4}$ In addition, debate participants were assigned one or two additional articles and were required to discuss all assigned material during the debate. Supplementary sources could be used to bolster their arguments, on the condition that these sources were either journalistic or peer-reviewed and were cited during the debate. 
On the day of a debate, audience members were required to submit a one-page response argument for or against the policy debate, based on the assigned articles. Audience members retained their responses until the end of class, and so could reference their written work to assist debate teams during work periods. This short assignment exposed the audience to the debate topic prior to the debate and encouraged their engagement during the debate.

As discussed in greater detail in the next section, we found that these activities stimulated significant student interest in, awareness of, and engagement with critiques of the textbook neoclassical model, and introduced students to perspectives rooted in social economics and/or political economy through the post-debate debriefing.

\section{Social economics and pluralist perspectives in IME: key contributions of class debates to student learning}

We present three aspects of in-class debates that are especially relevant to instructors who wish to integrate social economics and pluralist perspectives into IME. These emerge from qualitative analysis of notes taken during the debate and of student memos, as well as from qualitative and quantitative responses to the self-assessment survey.

\subsection{Attention to knowledge construction processes in data and theory}

The debates allow students to pay greater attention to the processes of knowledge construction through data collection and theoretical assumptions - that inform economic decision-making. Students are forced to confront the ideas that data or metrics might be insufficient to 'settle' an economic question, that policy can be based on flawed or inadequate data, and that problematic assumptions ingrained in NCE may drive inaccurate conclusions.

The typical approach to justify a debate position included an evaluation of costs and benefits related to that position. In the course of constructing counter-arguments, however, students quickly realized that while statistics supported arguments, they did not provide resolution. First, students recognized that any analysis of costs or benefits is limited by the ability to apply metrics in each case. Income, costs, and profits are objectively measurable, but measures such as health, happiness, or fairness are subjective, difficult to measure, and thus excluded from the calculus of cost or benefit. Such constraints are glaringly problematic for some debates. When debating the crime deterrence impacts of the death penalty, students found that it was relatively simple to gauge the direct costs of the death 
penalty, in terms of criminal justice expenditures, but that it was more difficult to monetize indirect costs such as emotional pain, distress, or the value of a life saved from a murder avoided. Students were thus forced to confront the limitations of data and of a rationalist framework that relies on marginal analysis as a means to maximize benefits.

Second, through this activity, students comprehend that normative assumptions about value drive processes of data collection and what is included as data, i.e. economic data are socially determined. Some students noted that social and institutional norms drove metrics such as wages or participation in the labor market. During the discrimination debate, for instance, students noted how gender norms could influence labor market behavior and result in persistent wage discrimination. The team used insights from feminist economics, which had not been discussed thus far in the course, demonstrating student-driven exploration. One student argued in their memo:

Societal implications such as the presence of certain qualities based on gender are deeply ingrained in America and allow for the unequal distribution of men and women in certain professions. The social constructs of gender also dictate how much time each spends on childcare and housework, which in turn affects the time they spend at the workplace and their experience and performance while there. Even with candidates who possess nearly identical experience and qualifications, racial and gender-based statistical discrimination remains in hiring by firms.

Third, the debate afforded students an opportunity to judiciously consider data collection methods, biases in the methods used to collect data, and the faulty conclusions such data might lead to. During the debate on charter schools, a student noted that selection bias - in which children apply to enroll in charter schools and cream-skimming by such schools skimming (Lacireno-Paquet, Holyoke, Moser \& Henig 2002) - limits empirical interpretations of their efficacy. The team further noted that the gap in student achievement across charter and public schools is further inflated since students with low academic achievement were subsequently overrepresented in public schools, which in turn may be used - problematically - as 'evidence' that charter schools are 'more successful'.

One explicit learning goal was to enable students to gain facility with the terminology and tools of the neoclassical model to examine its economic outcomes. For instance, in the debate Is discrimination on the basis of gender a major factor in US labor markets today? students drew graphs to demonstrate the impossibility of lasting discrimination according to the neoclassical model where employers hire the best workers. Similarly, during the debate Does the anti-sweatshop movement (ASM) help workers in developing economies? a student illustrated a typical labor market on the classroom whiteboard to explain how higher wages would incentivize workers in developing economies to enter formal labor markets and exit informal work, resulting in a lower equilibrium 
wage rate and higher unemployment in the formal sector due to anti-sweatshop activism. At the same time, however, the assumptions inherent in the model come under closer scrutiny, especially by teams arguing the opposite position. During the debate Should there be a 'fat' tax on junk food?, a student noted that, "Consumption of fatty foods might not be a choice," for families with just one item in their choice set: fatty foods. Student comments here echo pluralist approaches to rational choice theory, particularly the capability approach (Sen 1979; Sen 1999, parts of which may be assigned in the debriefing), arguing that economists should consider the menu of options in a choice set as indicative of a person's wellbeing rather than the outcome of choice determined by marginal analysis. Students become especially aware of how theoretical assumptions that underlie the neoclassical model - such as exogenous preferences - constrain their ability to make sense of real-world outcomes, and indeed, how preferences and the menu of options available are heavily influenced by social norms, moral values and structural conditions.

\subsection{Cognizance of power in socio-economic life}

The debates allowed students to use a political economy lens and to explore the role of power - as well as its perpetuation - in economic life (in creating and preserving endowments in favor of certain groups). In the debate Is discrimination on the basis of gender a major factor in US labor markets today?, students argued that the over-representation of men in leadership positions and of women in lower-level positions leaves few mentors for women in fields that are thus segregated. This observation provides a starting point for a discussion of alternative theories of the labor market and discrimination, which both challenge the human capital theory upon which the neoclassical understanding of discrimination relies, as well as explain persistent discrimination in labor markets (contrary to the neoclassical conclusion where competition eliminates discrimination as businesses with a 'taste' for discrimination are driven out by non-discriminators hiring the best resources). Students can then be introduced to select concepts in institutional and feminist economics, such as occupational segregation and segmented labor markets, in the debate debriefing.

Similarly, in the discussion on capital punishment, students recognized the intimate link between power, politics, and economic policy. Pointing out that the death penalty seldom proves to be a deterrent for crime, they reflected that one reason for its persistence is because politicians use it to signal a 'tough on crime' stance to the voting public and to gain political favor. The issue of power also arose in the discussion on big-box retailers. When students arguing in favor of the motion made a claim that workers - excluding those working part-time - in big-box stores did have medical benefits on average, the opposing team and the audience were quick to dispute this notion. One student 
argued that excluding part-time workers in analyzing whether workers were treated fairly might not be appropriate in a context where hiring part-time workers itself is a strategy pursued by large corporations to avoid paying benefits. Disputing the employment creation effects that big-box retailers are purported to have, students used the example of Wal-Mart to state:

Walmart is simply offering jobs to those unemployed by its own actions.

Students noted how big-box retailers with too much market power perpetuate a low-wage-low-skills cycle and also lead to high unemployment as local enterprises shut down. When the issue of alternative ways of organizing enterprises came up on one occasion, the debriefing session consisted of an introduction to cooperative and non-capitalist enterprises and the solidarity economy (excerpts from Kawano, Masterson and Teller-Ellsberg 2009).

Since neoclassical theory designates the household or business as the locus of decision-making, students quickly recognized the constraints this theory runs into when the problems are structural. The debates helped students step outside the domain of atomistic economic decision-making, and to propose solutions based on collective action and solidarity. This was most apparent in the debate Do ASMs harm workers in low-wage economies? In this debate, a student arguing in favor of the motion pointed to the danger of firms relocating should ASMs damage their profitability. In response, the other team advocated for the growth of a global ASM through worker solidarity and collective action, so exploitative corporations are forced to reduce their profit margins in favor of higher wages to workers. Similarly, one student emphasized during the debate that while the search for higher profits motivated outsourcing, educating consumers on the environmental and labor rights aspects of outsourcing was crucial to changing consumerist attitudes driving sweatshops in the first place.

Students frequently noticed how methodological individualism ${ }^{5}$ espoused by the conventional neoclassical model elides structural inequalities and the very processes that create preferences and endowments. For instance, in the debate and memo on the topic Should we impose a fat tax on junk food?, students noted how the argument that the consumption of junk food falls under the purview of individual choice fails in contexts where such choice may be socially constructed through heavy advertising and marketing campaigns, especially on television. One student memo linked the promotion of such consumption to capitalism, where businesses selling such foods must compete with one another through heavy advertising and marketing.

...the capitalistic environment that we live in in the US is dominated by large fast food and junk food companies that are able to spend massive amounts of money on marketing. Since these companies make large profits, they can spend billions trying to convince consumers to purchase their unhealthy 
products ... definitely impacts the consumer's true choice of what foods they choose to consume ...it is clear that this "choice" is weighted towards unhealthy foods.

Even as some students argued in favor of a tax to internalize the externalities junk food consumption places on society as a whole (in the form of rising health costs), others countered with the distributional implications of such a tax on low-income and time poor families who have little real choice but to consume such food. Thus, students concluded: 'Reducing inequality will help reduce demand for low-cost, high-caloric junk food.'

\subsection{Engagement with the economic justice, ethical, and historical dimensions of economic dilemmas}

Debate topics deliberately invite students to assess whether market outcomes are equitable or just, in contrast to efficient or profitable, as underscored by NCE. Preparing arguments for the debates and writing the policy memo also affords students an opportunity to question the value-neutrality of neoclassical assumptions. Rather than see the economy as a realm purely driven by the calculus of pain and pleasure, students recognize that it is socially embedded. Students are able to deconstruct the artificial and often farcical separation of economics from ethics, and examine the ethical and economic justice implications of decision-making and policy actions. Since much of the content at this level tends to emphasize the concept of efficient markets, students have the opportunity to consider the equity and distributive aspects of policy decisions based on this framework.

Through the debates on outsourcing and ASMs, students begin to understand the workings of capitalism and the role that conspicuous consumption in the West or corporate greed play in driving global demand for and supply of ever cheaper products at the cost of workers in the Global South. In the debate on ASMs, when one speaker attempted to separate the ethics of sweatshops from the economic bottom line, ['We will ignore the ethical question around sweatshops and look at this from the economic point of view'] other participants reacted swiftly and vigorously with objections. One student pointed out that firms themselves are conscious of the reputation effects of being connected to poor working conditions (especially in light of Foxconn employee deaths in China, or the fires in garment factories in Bangladesh), thereby calling to question the separability of ethics and business. The following excerpt from a policy memo on how ASMs contribute to improving working conditions, serves to illustrate that students understand the importance of ethics in ensuring wellbeing, and the potential correlation of worker well-being with other favorable economic outcomes, including profitability and the growth of local economies through consumption.

Empowered workers would also increase the quality of the products; workers would be happier and take more pride in their jobs, so the quality of the goods would increase and this could also increase 
profits. ... (Further) even small increases in wage could end up having a much larger impact on the economy through propelling local consumption.

In the debate on outsourcing/offshoring, similarly, students pointed to the high shares of corporate profit in the total value added for firms that engaged in offshoring. Further, they illustrated that these profits have been used to enhance shareholder value, rather than invest in productive assets (Milberg and Winkler 2010). The offshoring of dirty industries similarly provoked discussions around climate justice and how the poorest countries face the direst consequences from the relentless consumption propelled by rich countries.

In the course of preparing background information for the debates and memo, students also traced the historical antecedents of current practices. For instance, in talking about the role ASMs can play in advocating for normative policy changes, one student noted how developing countries face the same dilemmas that the US faced earlier in the twentieth century:

In the early days of capitalism, there were no regulations ... 63 women in Manhattan in 1920 working in sweatshop like conditions were burnt to death ...Fair labor laws (in the US) came into being much later (and ASMs could help bring about those changes sooner in developing countries).

Student research on the debate topics can thus point to avenues for policy or collective action based on historical precedent.

In one semester, the issues emerging from the debate on the 'fat' tax led to a student field trip to a local organization providing fresh produce to inner city neighborhoods and food deserts in upstate New York. While constraints around course schedule factor into organizing such activities, they are an important stepping-stone towards community-focused learning, advocacy, and activism (McGoldrick and Peterson 2009). Students may then carry out independent studies or research projects in later semesters with community partners if they can see the relevance of such engagement early on during their course work.

As Table 3 reports, most students strongly agreed (73 students or 37 percent) or agreed (99 students or 50 percent) that the debate exposed them to multiple perspectives and ethical dimensions of the issue under discussion.

\section{Caveats}

While the class debates showed promise in terms of student-driven exploration into critiques of NCE and alternative economic frameworks, some caveats do exist. 
One concern is that students do not obtain a comprehensive, in-depth knowledge of any particular alternative framework, and that their introduction to select concepts from alternative frameworks is partial. We argue, however, that the objective here is to introduce students to the possibility and existence of alternatives, rather than provide an in-depth knowledge of, and terminology associated with, each alternative framework. Students understand the assumptions and working of the NCE model as a first step in preparing for the debate. As a second step, through the resources students themselves bring in and through additional reading for debate debriefs, their discomfiture with NCE is built upon through a discussion of concepts from an alternative framework (institutionalist, Marxist, feminist, ecological, evolutionary) which point to the existence of other plausible ways to interpret reality. For instance, the idea of exploitation in Marxian economics may be introduced after the debate on ASMs, feminist political economy after the debate on gender discrimination in the labor market, and behavioral perspectives after the debate pertaining to junk food or marijuana legalization.

We also note here that since students drive the debate, the activity creates the opportunity for pluralistic inquiry but does not guarantee it. Some students may only acquire an awareness of the gaps between abstract theory and the real world, but even this first step and the application-oriented refocusing of course content through the debates is valuable in an IME theory course that students consider 'dry'. On the self-assessment survey reported in Table 3, 97 students (49 percent) strongly agreed and 86 students (44 percent) agreed that the debates had, at the very least, led them to make connections between economic theory and the real world.

Finally, this activity works well with a class size of around 20 to 50. Larger class sizes make the logistical aspects unwieldy.

\section{Conclusion}

The class debates activity outlined in this paper effectively engages students in theory-driven IME classes. It achieves multiple objectives of relevance to social economists. Students begin to consider economics as a socially and historically embedded body of knowledge, with deep ethical and political implications. In doing so, students recognize that there are other ways of 'doing economics' and begin to consider alternative lenses to analyze economic phenomena - be it the capability approach in unpacking choice, feminist analyses of discrimination in the labor market, perspectives from institutional economics on labor market segmentation, the distributive and ethical quandaries of 
outsourcing, or the political economy of ASMs. Fundamentally, students recognize that norms, values, and ethics are intimately tied to questions about who the economy is for.

Additionally, through the bottom-up approach facilitated by class debates in IME, the instructor merely acts as a facilitator during the debate, leaving students to 'develop their voice and participate as active agents in economic conversations' (Emami 2015: 86). Depending upon the direction the debates take and the level of student interest, however, the instructor can extend discussion in the next class session through assigning additional resources that present alternative perspectives in some greater detail. The activity also serves to validate the thinking processes of students who are attempting to articulate their discomfort with the narrow methodological individualism of NCE. Exposure to and learning from hands-on activities - in which students arrive at a greater understanding of the ethical and economic justice implications of normative policy-making on these issues through mutual discussion and their own research (as opposed to being 'talked at' by an instructor) - are more likely to promote engagement, mastery, and self-directed learning (Johnson, Johnson \& Smith 2000; Prince 2004).

This activity is adaptable to a variety of contexts and course lengths. We have included examples of topics that are particular to the US context; debates may, however, easily be set up to include the examination of existing economic analyses on local and national issues of importance in non-US contexts. While we adopt an 'orthodox-plus' approach in our discussion as a practical response to an atmosphere where NCE dominates in terms of availability of textbooks and instructor resources, we note that the activity may also be carried out in an IME class that is already pluralist in content. In such a case, the debates add the application element which drive bottom-up processes of learning and discovery in students.

\section{Acknowledgments}

We thank the participants in a session on 'Pluralist Approaches to Teaching' at the International Confederation of Associations for Pluralism in Economics (ICAPE) Conference, held in Chicago on January 4, 2017, Richard McIntyre, Robert Van Horn, Jessica Carrick-Hagenbarth, and three anonymous reviewers for their comments and questions, which helped us clarify the discussion in this paper. We also thank the students in our intermediate microeconomics classes for their enthusiastic participation in this project. The usual disclaimers apply.

\section{References}

Basker, E. 2005. 'Job Creation or Destruction? Labor Market Effects of Wal-Mart Expansion,' Review of Economics and Statistics 87(1): 174-183.

Becker, W. E. 2004. 'Economics for a higher education.' International Review of Economics Education 3(1): 52-62. 
Colander, D. 2000. 'The death of neoclassical economics.' Journal of the History of Economic Thought 22(2): 127-143.

Colander, D., R. Holt, and B. Rosser Jr. 2004. 'The changing face of mainstream economics.' Review of Political Economy 16(4): 485-499.

Denis, A. 2009. 'Editorial: Pluralism in Economics Education.' International Review of Economics Education 8(2): 6 - 21.

Dequech, D. (2007). 'Neoclassical, mainstream, orthodox, and heterodox economics.' Journal of Post Keynesian Economics 30(2): 279-302.

Emami, Z. (2015). 'Teaching and Learning in Economics.' Elgar Companion to Social Economics, edited by J.B. Davis and W. Dolfsma, Northampton MA: Edward Elgar, 82 - 101.

Garnett, R.F. 2006. 'Paradigms and Pluralism in Heterodox Economics.' Review of Political Economy 18(4): 521 - 546.

Guthman, J. 2011. Weighing In: Obesity, Food Justice, and the Limits of Capitalism. Berkeley and LA: University of California Press.

Hess, D.E. 2004. 'Controversies about controversial issues in democratic education.' Political science and politics 37 (2): 257-261.

Holcombe, R.G. 2008. 'Pluralism versus Heterodoxy in Economics and the Social Sciences.' The Journal of Philosophical Economics 1(2): 51-72.

Johnson, D., R. Johnson, and K. Smith. 1991. Active learning: Cooperation in the College Classroom. Edina, MN: Interaction Book Company.

Kawano, E., T. Masterson and J. Teller-Ellsberg (2009), Solidarity Economy I: Building Alternatives for People and Planet, Papers and Reports from the 2009 U.S. Forum on the Solidarity Economy, Amherst MA: Center for Popular Economics.

Lacireno-Paquet, N., T. Holyoke, M. Moser and J. Henig. 2002. 'Creaming Versus Cropping: Charter School Enrollment Practices in Response to Market Incentives.' Educational Evaluation and Policy Analysis 24(2): 145-158.

Lee. F.S. 2011. 'The Pluralism Debate in Heterodox Economics.' Review of Radical Political Economics 43(4): 540 - 551.

Mearman, A. 2007. Teaching Heterodox Economics Concepts. The Economics Network. Available at: https://economicsnetwork.ac.uk/handbook/printable/heterodox.pdf. Retrieved: September 30, 2016.

Mearman, A. 2008. 'Pluralism and heterodoxy: Introduction.' Journal of Philosophical Economics $1(2): 5-25$.

Milberg, W., \& D. Winkler (2009). 'Financialisation and the dynamics of offshoring in the USA.' Cambridge Journal of Economics 34(2): 275-293. 
Neumark, D., J. Zhang and S. Ciccarella. 2008. 'The Effects of Wal-Mart on Local Labor Markets.' Journal of Urban Economics 63(2): 405-430.

McGoldrick, K.M., and J. Peterson. 2009. 'Public scholarship and economics: engaging students in the democratic process.' Forum for Social Economics 38(2-3): 229-245

Peterson, J., and M. Lewis. 2001. (eds). The Elgar Companion to Feminist Economics.

Northampton MA: Edward Elgar.

Polanyi, K. (1944), The Great Transformation. New York: Rinehart.

Prince, M. 2004. 'Does Active Learning Work? A Review of the Research.' Journal for Engineering Education 9(3): 223-231.

Sen, A. 1999. 'Poverty as Capability Deprivation,' Development as Freedom, New York: Anchor Books.

Shulman, S. 1996. 'The Political Economy of Labor Market Discrimination: A Classroom-Friendly Presentation of the Theory.' Review of Black Political Economy 24(4): 47-64.

Stilwell, F. 2016. 'Heterodox Economics or Political Economy?' World Economics Association Newsletter 6(1): 2 - 6.

Weintraub, E.R. 2007. 'Neoclassical Economics.' The Concise Encyclopedia of Economics (online). Available at http://www.econlib.org/library/Enc1/NeoclassicalEconomics.html. Retrieved September 25, 2016.

Woolley, F. R. 1993. 'The feminist challenge to neoclassical economics.' Cambridge Journal of Economics 17(4): 485-500. 
- Provencher, A. and S. Ramnarain (2018), Class Debates in Intermediate Microeconomics: Social Economics and Pluralist Perspectives, Forum for Social Economics, 1-19, https://doi.org/10.1080/07360932.2018.1447494

1 Two examples are CORE and the textbooks developed by the Global Development and Environment (GDAE) Institute at Tufts. Both focus, however, on introductory economics.

2 The difference between pluralism and heterodoxy, and debates on this difference discussed in the work of Holcombe (2008), Garnett (2006), Lee (2011) and others is acknowledged. A detailed discussion is beyond the scope of this paper.

3 The debate structure can be varied depending on available time and number of participants per team. For instance, the instructor may choose to have a six-minute opening arguments section if teams have more members, or relegate more time for audience questions.

4. We found that assigning such articles had the added benefit of introducing students gradually - sophomores, especially, who were taking an intermediate-level class for the first time - to journal articles.

5 Students did not explicitly use the term 'methodological individualism', but their arguments hinted at this idea during the debate. Debriefing can introduce this term more formally. 
Table 1. Debate questions and relevant microeconomic concepts

\begin{tabular}{ll}
\hline Debate question & Microeconomic concepts \\
\hline $\begin{array}{l}\text { Is the death penalty an efficient crime } \\
\text { deterrent? }\end{array}$ & $\begin{array}{l}\text { Cost-benefit analysis; Efficiency; Opportunity } \\
\text { cost; Elasticity }\end{array}$ \\
$\begin{array}{l}\text { Is college education a good investment? } \\
\text { Cost-benefit analysis; Opportunity cost; } \\
\text { Income and substitution effects; Consumer } \\
\text { choice theory }\end{array}$ \\
$\begin{array}{l}\text { Poes the anti-sweatshop movement help } \\
\text { porkers in developing economies? }\end{array}$ \\
$\begin{array}{l}\text { Should there be a 'fat' tax on junk food? } \\
\begin{array}{l}\text { Should we allow more charter schools in New; Comparative advantage } \\
\text { York? }\end{array}\end{array}$ \\
$\begin{array}{l}\text { Are big box retailers good for the US } \\
\text { economy? }\end{array}$ \\
$\begin{array}{l}\text { Consumer choice theory; Public goods; } \\
\text { Should marijuana be legalized? }\end{array}$ \\
$\begin{array}{l}\text { Is discrimination on the basis of gender a } \\
\text { major factor in US labor markets today? }\end{array}$ & $\begin{array}{l}\text { Cost minimization; Profit maximization } \\
\text { Consumer choice theory; Externalities }\end{array}$ \\
\hline
\end{tabular}

Table 2. Debate structure

\begin{tabular}{ll}
\hline Round and description & Time for each team and order \\
\hline Round one: Position presentation & 4 minutes; Pro team first \\
Work period & 4 minutes \\
Round two: Rebuttal & 3 minutes; Pro team first \\
Work period & 4 minutes \\
Round three: Response & 2 minutes; Con team first \\
Round four: Audience questions & 3 minutes; Pro team first \\
Work period & 4 minutes \\
Round five: Position summary & 2 minutes \\
\hline
\end{tabular}


Table 3: Self-assessment survey results

Percentage of students in strong agreement or agreement that a learning outcome was achieved. $\mathrm{N}=$ 196.

\begin{tabular}{llc}
\hline Learning self-assessment & Strongly agree & Agree \\
\hline $\begin{array}{l}\text { Debate allowed me to critically analyze and interpret economic } \\
\text { data }\end{array}$ & $42 \%$ & $45 \%$ \\
$\begin{array}{l}\text { Debate enabled me to apply economic reasoning to the analysis } \\
\text { of the topic under discussion }\end{array}$ & $39 \%$ & $49 \%$ \\
$\begin{array}{l}\text { Debate helped me appreciate the limitations of neoclassical } \\
\text { microeconomics in real world situations }\end{array}$ & $49 \%$ & $44 \%$ \\
$\begin{array}{l}\text { Debate alerted me to the ethical and historical dimensions of } \\
\text { economic dilemmas }\end{array}$ & $37 \%$ & $50 \%$ \\
$\begin{array}{l}\text { Structure and format of the debate was suitable for unpacking the } \\
\text { central issues related to the topic }\end{array}$ & $41 \%$ & $47 \%$ \\
\hline
\end{tabular}

